\title{
UNEMPLOYMENT AND HOMELESSNESS IN THE CITY OF POZNAŃ IN 1929-1939
}

The Polish National General Exhibition (PWK, also known as "Pewuka") was held in Poznań in 1929. It was meant to be and it did become a showcase of the economic, industrial, social and cultural achievements of the Polish State, newly reborn in 1918, in the aftermath of the Great War. Staging of the Exhibition coincided with the advent of the economic crisis. Preparations for the Exhibition required an enormous amount of work, and considerable investments were needed to build a suitable infrastructure. Poznań became a huge building site, with many labourers coming to the city in search of employment. After 1929 those labourers added to the large group of the unemployed in the aftermath of the great economic crisis. During the 1930s the unemployment and the related problems aggravated the housing crisis in Poznan. The city authorities attempted to resolve this problem by putting the homeless up in the former exhibition grounds recently vacated following the closure of the Polish National General Exhibition. It was only an interim measure. In search of a more permanent solution, the city started to redevelop allotments or community gardens by building purpose-built residential garden huts or sheds.

Keywords: The Polish National General Exhibition, PWK, Pewuka, the post-exhibition grounds, the homeless, the unemployed, social care, allotments, community garden estates.

doi:10.2478/sho-2014-0005

The Polish National General Exhibition was held in Poznań in 1929 and, at the time, it was an unprecedented event. The newly reborn Polish State organised this event in order to give Poles a feeling of recovery in the aftermath of war and which promoted Poland's achievements and contribution to science, technology, industrial design and the arts. Commentators have often stressed the political importance of this event, as proof of Poland's aspirations and desire to the young state to overcome the lack of economic development and growth after more than a century under foreign occu- 
pation following the partitions ${ }^{1}$. However, we prefer to see the Exhibition as proof of the economic and organisational potential of both Poland and of the city of Poznań. The Polish National General Exhibition (PWK) was staged during a very special period of time. Even while the show was still on, the tensions loomed large brought about by the advent of the economic crisis. The effects of the crisis soon started to be felt on an increasingly larger scale. This, in fact, was one of the reasons why the Exhibition was hastily liquidated soon after it had officially closed ${ }^{2}$.

The organisation of the exhibition and all the investments needed to stage this huge event triggered a major influx of people into Poznań. There was a demand for a lot of labourers to build the exhibition facilities, to upgrade and expand the city infrastructure and to provide administrative and technical services while the exhibition and accompanying events were on. The economic crisis which started in 1929 meant that many of those labourers were left without employment once the show closed. Rising unemployment contributed to the rising number of homeless in the city. Resolving the problem of homelessness became a pressing issue for the Poznan authorities. One of the solutions that the city came up with was to put the homeless up in the former exhibition facilities vacated after the closure of the Polish National General Exhibition, all located in the " $E$ " sector of the exhibition grounds.

The objective of this article is to show the circumstances in which this provisional measure was adopted and to present the endeavours of the city to resolve the problem of the homeless in Poznan at the time of the economic crisis. The timeline dealt with here is from 1929-1939, i.e. the time from the PWK Exhibition until the outbreak of the World War II. A reservation has to be made here that the issues of unemployment, homelessness and the housing conditions in Poznan will be presented in a slightly wider context, including the situation from the times before the economic crisis, in order to present a wider background for comparison. Despite the fact that economic history books generally see the years 1935-1936 as being the end of the economic crisis in Poland ${ }^{3}$, the situation with housing was improving only at a very slow rate. The objective of this study is to present the influx of manual labour into Poznań, attracted by work available on

${ }^{1}$ M. R. Bombicki, Powszechna Wystawa Krajowa w Poznaniu 1929, Poznań 1992, pp. 3-4, 8.; P. Wachowiak, Czasy, które przeżyłem. Wspomnienia z lat 1890-1939, Warszawa 1983, p. 213.

2 M. R. Bombicki, op. cit., p. 189.

${ }^{3}$ W. Morawski, Dzieje gospodarcze Polski, Warszawa 2011, p. 208. 
the Polish National General Exhibition (PWK) project, and to show this process in the context of the growing economic crisis and the unemployment and homelessness closely associated with the crisis. The paper also undertakes to show those developments against the background of the efforts of the city authorities to provide social care, to create jobs for the unemployed and to provide dwellings for the homeless.

\section{THE 1929 POLISH NATIONAL GENERAL EXHIBITION IN POZNAŃ}

The initiative to stage the exhibition in Poznań came from Cyril Ratajski, the city's Mayor (called the City's "President" in Polish), in 1926, after the original idea of holding this event in Warsaw had been abandoned ${ }^{4}$. It was mainly a concept to stage an event emphasizing trade and the economy. Cyril Ratajski's intention was to showcase Poland's economic progress, and by virtue of such a show to try to prove that Poland had not wasted the chance it had been offered ${ }^{5}$. The additional motivation was undoubtedly to promote Poznań as Poland's main exhibition centre, and thus to secure funding to facilitate further expansion of the city.

Unlike Poland's capital at the time, Poznan did have suitable infrastructure to stage such an exhibition, and it did have the necessary experience and expertise in staging international trade fairs. The initiative to organise fairs in Poznań originated in 1920. Initially, the fairs were restricted to local Polish participants. It was not until the fifth edition of the Poznan Fair in 1924 that it became an international event ${ }^{6}$. Poznan International Fair (MTP - Międzynarodowe Targi Poznańskie) became a member of the Union of International Fairs (UIF) ${ }^{7}$. Proper expansion of the exhibition infrastructure started in 1924. The plan was to concentrate the previously scattered exhibition grounds into one venue. The city purchased the land in the vicinity of the Górnośląska Tower and construction of exhibition facilities commenced soon afterwards. Those included the so-called Patac Targowy ("The Palace of Fairs") and the buildings to accommodate the PIF

\footnotetext{
${ }^{4}$ M. R. Bombicki, op. cit., p. 13.

${ }^{5}$ P. Wachowiak, op. cit., p. 179.

6 Targi Poznańskie [in:] Księga pamiątkowa miasta Poznania, Z. Zaleski (Ed.), Poznań 1929, p. 656.

${ }^{7}$ Ibidem, p. 659.
} 
administration offices. In 1928 the 7,200 sq. metre "Central Hall" opened, while building work continued on the grounds along Bukowska Street ${ }^{8}$.

The Poznan Fair was gradually becoming an important economic and business event. From 1925 it started to attract increasing numbers of exhibitors from outside of the Wielkopolska region, and in 1928 as many as $42 \%$ of the exhibitors were international participants ${ }^{9}$. The Fair also put Poznań under pressure to develop a suitable hotel and accommodation infrastructure for the visitors. Moreover, the Poznan Fair greatly expanded its own contacts and relations with leading businesses and business leaders as well as with members of the media both in Poland and abroad. Promotional leaflets were printed in as many as 11 languages; tours were organised for foreign visitors, and a number of events were organised to accompany the Fairs. Obviously, one of the key factors was Poznan's geographic location and the city's proximity to Poland's western border, a fact which greatly facilitated contacts with potential foreign partners and exhibitors. The Fairs were an important manifestation of the spirit of entrepreneurship and drive to embark upon economic growth. All those assets and strengths meant that the organisation of the Polish National General Exhibition was awarded to Poznań. It was a massive challenge, and the costs of building the exhibition facilities, building the streets as well as the redevelopment of the land for the Fair and subsequent administration of the Fair grounds were to be borne by the city. In addition, Poznan undertook to complete, before the show was due to open, a number of additional investments, such as a stadium, a shelter home for lonely or single individuals, as well as to provide accommodation for 5,000 visitors ${ }^{10}$.

The total cost of the PWK Exhibition was between 80-100 million zlotys. This included the PWK's own budget, initially estimated at 15 million zlotys, which reached with time 22-24 million zlotys. The remaining costs were split between the city of Poznan and the exhibitors (including the government of the Republic of Poland as an exhibitor in its own right). The city was subsequently to purchase the PWK infrastructure at a cost of $25 \%$ of its value. Total spending on the construction work and preparations for the exhibition closed at around 30-35 million zlotys ${ }^{11}$.

\footnotetext{
8 Ibidem, pp. 661-662.

${ }^{9}$ Ibidem, p. 663.

${ }^{10}$ P. Wachowiak, Rys historyczny Powszechnej Wystawy Krajowej w Poznaniu w roku 1929, Poznań 1930, p. 17.

11 Obszerne fragmenty wspomnień dr Stanisława Wachowiaka. Likwidacja Powszechnej Wystawy Krajowej, [in:] M. R. Bombicki, op. cit., p. 184.
} 
The Polish National General Exhibition lasted from the $16^{\text {th }}$ of May until the $30^{\text {th }}$ of September 1929. In all, 112 various buildings and facilities were built for the show. At the time when the construction and building work was at its most intensive, there were some 1,200 people employed on site on a daily basis, with a further 3,000 or so employed at various workshops and contractor facilities which acted as PWK suppliers ${ }^{12}$. After the exhibition closed, work still continued in order to complete some of the investments started earlier in connection with the PWK Exhibition. The largest project by far was the completion of an electric power plant for the city. Władysław Czarnecki estimates that, thanks to the economic boom associated with the Exhibition, Poznan started to feel the impact of the economic crisis some two years after this impact hit other parts of Poland ${ }^{13}$. While those estimates seem exaggerated, there is no doubt that Poznan enjoyed quite an economic boom at the time of the exhibition: unemployment was low and pay was generally rising.

The PWK Exhibition grounds were divided into several sectors:

- Sector A comprised the Poznań International Fair buildings and facilities;

- Sector B comprised the new buildings and facilities designed and built with a view to being used in the future by other organisations and institutions (Collegium Chemicum and Collegium Anatomicum, the 'Polonia' Hotel, The School of Business and Commerce);

- Sector C was located around Wilson Park;

- Sector D was located inside the grounds occupied by the existing housing;

- Sector E (the largest sector with an area of 343,000 sq. metres) was located in the Łazarz district, in open grounds that had not been previously used by the city. The PWK facilities erected in that sector were of temporary character ${ }^{14}$. The majority of those grounds were used for agricultural exhibitions, to display food products and farm produce as well as farm machinery. The sector featured a special building where agricultural organisations and associations exhibited, a hall dedicated to forestry and hunting, another hall for the wood industry exhibition and a pavilion to

12 Wł. Czarnecki, To był też mój Poznań. Wspomnienia architekta miejskiego z lat 1925-1939, Poznań 1987, p. 86.

13 Ibidem, p. 88.

${ }^{14}$ G. Kodym-Kozaczko, Rozwój Poznania w planowaniu urbanistycznym w latach 19001990 [in:] Architektura i urbanistyka Poznania w XX wieku, T. Jakimowicz (Ed.), Poznań 2005, p. 33. 
display the achievement of the landowners ${ }^{15}$. The " $E$ " sector also included the arena and a fun fair.

After the show closed the problem remained of how to utilise the former exhibition grounds and infrastructure. The PWK Board was expecting that the City would take over all the PWK assets and liabilities following the closure of the exhibition, thus taking care of and resolving the problem of all the settlements between the PWK Board and the City. There was also a proposal for the City to purchase all the former exhibition grounds and facilities for $25 \%$ of their estimated value, at a cost of 4 million zlotys ${ }^{16}$. Initially, the former exhibition facilities in the " $E$ " sector were to be dismantled or demolished. However, it was also suggested to keep and utilize some of the buildings, especially the permanently built structures, such as the hall used to exhibit the products of the glass works, the sugar making industry and the fertilizer manufacturing industry ${ }^{17}$. There were even organisations willing to take over some of the buildings. For instance, the Parish of Our Lady of Sorrows in the Łazarz district approached the authorities with the proposal to lease two buildings, one to be used as a provisional church for residents around Matejki and Wyspiańskiego streets, and the other to be adopted as a meeting room ${ }^{18}$. In the event, municipal authorities decided to keep the buildings and to use them for the International Transportation and Tourist Show that was held from 6 July to 10 August 1930.

Due to the rising numbers of the homeless and due to the overcrowding in the shelters run by the city, the Mayor of Poznan issued a regulation on 30 October 1930, ruling that the former " $E$ " sector of the exhibition grounds with the buildings be handed over to the Department of Housing and Social Care in order to be adopted as dwellings for the homeless ${ }^{19}$. It would appear that the regulation by Mayor Ratajski only sanctioned the existing state of affairs because, at least as of early October 1930, former exhibition buildings had already been used to accommodate the home-

${ }^{15}$ M. R. Bombicki, Powszechna Wystawa Krajowa..., p. 37-38. Full list of PWK facilities located in the 'E' Sector, Ibidem, pp. 84-86.

16 List Zarzadu PWK do Rady m. Poznania z 16. 12. 1929, State Archives in Poznań (APP), City of Poznań Records, ref. 2469, p. 118.

17 Aktywa Powszechnej Wystawy Krajowej podlegajace likwidacji, AAP, City of Poznań Records, ref. 2469, p. 94.

${ }^{18}$ List proboszcza Parafii Matki Boskiej Bolesnej na św. Łazarzu w Poznaniu do Prezydenta m. Poznania z 14.11.1929, APP, City of Poznań Records, ref. 2469, p. 5.

${ }^{19}$ Wydziat Opieki Społecznej do Biura Mieszkaniowego Magistratu Stołecznego miasta Poznania z dnia 4.11.1930, APP, City of Poznań Records, ref. 4116. 
less. Since there were no more places in the shelters run by the municipal authorities, the former exhibition facilities were also used to accommodate families from ruined residential buildings that were in danger of collapsing ${ }^{20}$.

\section{SOCIAL CARE AND SOCIAL SECURITY IN POZNAŃ IN THE PERIOD BETWEEN THE WARS}

The city of Poznań boasted a very well developed system to provide assistance to the poor, the homeless and the beggars. The social care system had been modelled on the system used in Germany at the time. The city was divided into districts (there were 27 districts in 1929), with each district having its own committee for social care. Until 1928 the municipal department dealing with social issues was called The Deputation for the Poor (Deputacja Ubogich), and from 1928 the Municipality Commission for Social Care (Gminna Komisja Opieki Spotecznej) was established ${ }^{21}$. A special Department of Social Care was established within the city administration. In 1923 the staff numbered 27 office staff and 20 "sisters" or nurs$\mathrm{es}^{22}$. When the suburban boroughs (gminas) were incorporated into the city in 1925, this resulted in a rapid increase in the number of people who required support. This in turn put pressure on the city to commit to more investments in order to alleviate the problem. In 1927 enough money had been collected from levies paid by taxpayers in return for the permission to display "No Beggars" signs (84,000 zlotys) to fund building a new home for the elderly at No. 26 Grobla Street. In 1928 construction commenced of another shelter for single homeless people and of some more flats in the Zawady area ${ }^{23}$.

${ }^{20}$ In September 1930 there was a plan to relocate the families living in the former Rocha Street shooting range to the post-exhibition grounds. In October relocation started for the families from Rocha Street, from the former home for the elderly in Knapowskiego Street, and residents from Wenecjańska Street. By October 6, 1930 at least 44 families had already been relocated to the former exhibition grounds. Wydziat Opieki Społecznej do Wydziału XIIa $z$ dnia 6. 10. 1930 r. AAP, City of Poznań Records, ref. 4116.

${ }^{21}$ Opieka nad ubogimi, [in:] Księga pamiątkowa miasta Poznania, Z. Zaleski (Ed.), Poznań 1929 , p. 429.

22 Ibidem, p. 432.

${ }^{23}$ Ibidem, p. 436. 
The care and assistance to the poor at the time comprised the following: care for half-orphans, care for the elderly, care for the disabled, the incurably ill, the mentally handicapped, the persons unable to work, the homeless and the unemployed, victims of war, re-emigrants, the persons who opted for the Polish citizenship, as well as for former prisoners. It also involved co-operation with various charity institutions and organisations as well as attempts to eliminate begging in the streets, vagrancy and prostitution $^{24}$. Along the social care programs organised by the municipal authorities there were a number of other charity institutions and organisations, such as Caritas, Cheap Soup Kitchens (Tanie Kuchnie), Congregation of the Mission of Saint Vincent de Paul or Sisters of Saint Elizabeth ${ }^{25}$.

In 1922 the Union of Merchants' Associations of Poznań (Zwiazek Towarzystw Kupieckich) postulated that the Municipal Authorities started to provide some care to the beggars (their number at the time was estimated at 500), in exchange for an extra tax which traders were willing to pay towards this specific purpose. Members of the Association who were paying this tax were entitled to put a sign on the façade of their shops which read "No Beggars - This company pays the required taxes"26. This move, however, failed to yield the expected results. While merchants and property owners were very willing to pay this additional, albeit small, levy, this did not help to resolve the problem of begging in the streets. Then, in 1926, a special Anti-Begging Committee was established. The idea was to combine the efforts of various social care and assistance organisations and institutions, such as the Provincial Department of Social Care, the City Department of Social Care, the Local School/Education Authority (Kuratorium Szkolne), the State Police, the "Caritas" Charity Organisation and several other organisations of merchants and property owners. The system was based on police supervision and involved compulsory relocation of beggars to a compulsory labour establishment in Bojanowo (for those who were capable of work) or to the Establishment for the Poor in Śrem. In 1927 the expansion of the Municipal Establishment for the Elderly (Miejski Zakład dla Starców) with some 115 places was completed. In 1930 a decision was made to expand this institution by adding further 150 places. However, growing demand for places meant that the city decided to build a new Municipal Home for the Elderly at No. 6 Mostowa

\footnotetext{
${ }^{24}$ Ibidem, pp. 432-433.

25 Ibidem, p. 437.

${ }^{26}$ K. Król, Żebractwo we wspótczesnej Polsce jako kwestia społeczna, Konin 2010, p. 36.
} 
Street. With 270 places, the new home opened in March 1935. The number of residents soared from 174 in 1935 to 338 in 1937. In individual years during that period the following numbers of beggars were apprehended in the streets of Poznań: 1933/34 - 1223, 1934/35 - 745, 1935/36 - 499, $1936 / 37-274^{27}$.

\section{UNEMPLOYMENT IN POZNAŃ IN 1929-1938}

Poznan struggled with unemployment for nearly the entire twentyyear period between the world wars. A particularly significant increase in the number of the unemployed was seen in 1925 and 1926, especially during the winter time when seasonal work stopped and temporary employment became unavailable. At the time public works were initiated, mainly raking the bed of the Warta river and levelling and grading the grounds of the former forts. From 1927 the lack of work available (especially for skilled labour) became less of a problem. The labour situation improved further in 1928 when work started as preparations from the PWK Exhibition got underway. Poznań started to attract a large influx of labourers ${ }^{28}$.

Before the PWK Exhibition began, Poznań was an extremely busy place with intensive work going on in several locations. There was a shortage of labour and people did not have problems finding work. This is how Władysław Czarnecki recalled the frantic days immediately before the Exhibition officially opened:

The exhibition grounds (covering 60 hectares of land) became a huge building site, a true beehive of activity as lots of wagons and lorries would come in. Some were bringing goods and supplies, others would transport their loads away. Inside exhibition halls and buildings one could hear the pounding of hammers, nailing and fastening of materials and setting up of exhibits - there were forever things missing and people were needed all the time. To get a decorator or a carpenter to get things fixed was next to impossible. People spent the last three nights before the exhibition opened working round the clock to make sure things get finished on time. It was as if everyone worked themselves into a frenzy of some kind. People were on their last legs, but they carried on working regardless ${ }^{29}$.

${ }^{27}$ Ibidem, p. 40-42.

28 Z. Zaleski, Praca i ubezpieczenia społeczne [in:] Księga pamiątkowa miasta..., p. 262.

${ }^{29}$ Wł. Czarnecki, op. cit., p. 76. 
Indeed, the number of unemployed in 1929 did decrease significantly, and in April and May when the preparations were at their most intense, unemployment was at its lowest for that year. However, such a low level of unemployment continued only for a short time. As was to be expected, as soon as the PWK Exhibition opened in May 1929, the majority of labourers employed for the building and construction work were released ${ }^{30}$. As an organization, the PWK Exhibition employed only around 700 technical staff with a further 222 people working in administration ${ }^{31}$.

Unfortunately, statistical data for 1933-35 is not available. This data was not included in the Roczniki statystyczne stołecznego miasta Poznania ["The Statistical Yearbooks for the Capital City of Poznań"] nor was it included in Sprawozdania Zarzadu Miasta Stołecznego Poznania. ["The Reports by the Administration of the Capital City of Poznań"]. On the basis of the figures shown in table 1 we can infer, however, that the number of the unemployed was systematically on the rise. At the same time, overall numbers of individuals eligible to receive benefits from the Unemployment Fund were limited and were as follows: 1928 - 684 people, 1929 - 1062, $1930-2,662,1931-2,980,1932-2,654^{32}$. Those numbers amount to thousands of the unemployed without eligibility to claim unemployment benefits. It was not until 1938 that a marked drop in the number of the unemployed was reported, with the annual average of the unemployed totalling $11,225^{33}$. Fluctuations in the number of unemployed during the year were related to the fact that seasonal jobs would become available in the spring and summer period.

The Polish National General Exhibition certainly contributed to the reduction of unemployment. In the period leading up to the show, with increased demand for labour, a large number of people coming to Poznan from other areas found employment. Unfortunately, this significant influx of people only exacerbated the growing unemployment after the Exhibition closed. It was estimated that in May 1932 the overall number of the unemployed with their families reached some 26,000 which represented 10\%

${ }^{30}$ E. Makowski, Bezrobotni w Poznaniu w latach 1929-1939, part 1, W okresie kryzysu gospodarczego (1929-1934), Kronika miasta Poznania, No. 1 / 1974, p. 35.

31 Obszerne fragmenty wspomnień dr Stanisława Wachowiaka. Likwidacja Powszechnej Wystawy Krajowej [in:] M. R. Bombicki (Ed.), op. cit., p. 182. List Prezesa Zarzadu PWK do Prezydenta m. Poznania z 19. 08.1929, AAP, City of Poznań Records, ref. 2469, p. 66.

${ }^{32} \mathrm{H}$. Maciejewski, Położenie robotników przemysłowych w Wielkopolsce w latach 19291939, Warszawa 1964, p. 48.

33 E. Makowski, Bezrobotni w Poznaniu w latach 1929-1939, Part I, W okresie pokryzysowym 1935-1939, Kronika miasta Poznania, No. 1 / 1976, p. 62. 


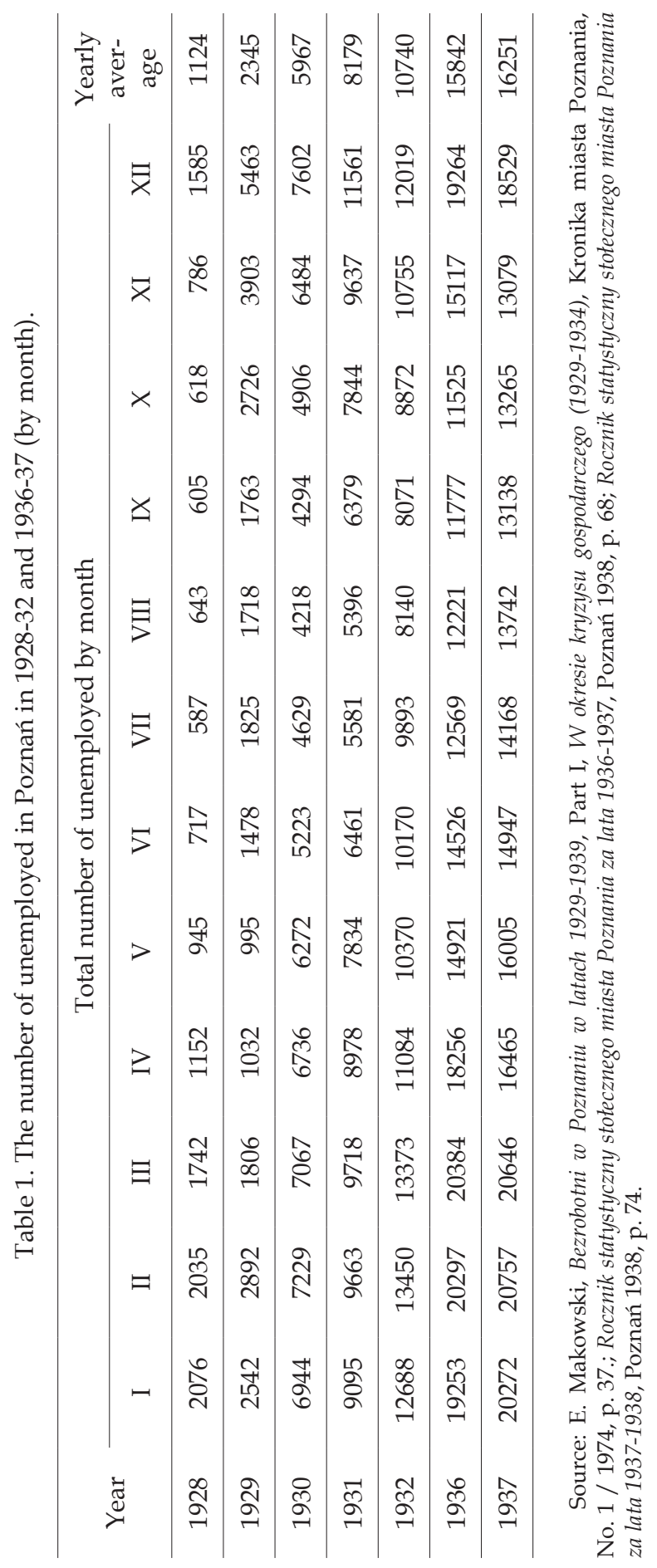


of the city's entire population ${ }^{34}$. The municipal authorities tried all sorts of ways to combat unemployment including securing loans from the state government to fund investment projects in the city (as subsidised intervention projects to create jobs) such as construction new buildings and regulation of the Warta River bed. There were also organised attempts not to allow former servicemen discharged from the military to stay in the city unless they originally hailed from Poznan. The police had a duty to remove the unemployed from the city if they were not registered. Workers who had lived in Poznan less than a year were most likely to be made redundant in the first place, presumably on the assumption that they would return to their native places. For this reason, when subcontracting work, the municipal authorities stipulated that contractors must not employ labourers who had lived in Poznan less than 5 years. This requirement, it appears, was meant to restrict the influx of external manual labour into the city. Another interesting proposal, almost revolutionary at the time, was the idea put forward by the Polish Association of Trade Unions (Zjednoczenie Zawodowe Polskie or Polnische Berufsvereinigung) to scrap unemployment benefits and use the money instead as an incentive to employers who would be willing to hire the unemployed by "paying them the difference between the unemployment benefit subsidy and the actual worker's pay". There were also moves to curb the practice of employing retired pensioners and students ${ }^{35}$.

On January 29, 1931 the unemployed staged a demonstration during which they presented Mayor Ratajski with a petition in which they demanded, among other things, to be given work, immediate aid (in the form of food, clothing, and solid fuel for heating), provision for breakfast and lunch meals for schoolchildren of the unemployed and of the homeless, provision for milk and food for the small children at the nursery age for the duration of the period their parents remain out of work ${ }^{36}$. However, even had all those demands of the unemployed been met, it would have eased their problems only for a short time. The number of available jobs was not increasing, while the resources to be earmarked for social security were limited.

The State Labour Fund (Państwowy Funduszu Pracy) was established in 1933, and a high tax was subsequently imposed on all employed individuals to contribute to the PFP Fund. This fund supported local govern-

\footnotetext{
${ }^{34}$ H. Maciejewski, op. cit., p. 49.

${ }^{35}$ Ibidem, p. 55.

36 Ibidem, p. 58.
} 
ments with subsidies, loans and financial aid aimed at job creation and hiring of the unemployed. The simplest solution was to organise subsidised intervention work projects to employ large numbers of unskilled workers. However, funds were lacking to organise such intervention projects on a large scale. In 1934 a conference was organised in Poznan which brought together directors and managers of the municipal utility companies, the Town Hall officials and representatives of the Labour Fund. The objective of this meeting was to assess the potential for providing jobs to the unemployed around the city. It turned out the possibilities were very limited. The local Water Supply Company declared it could employ up to 200 people per week, the Municipal Gardens offered another 200 jobs and the City Department of Housing could take on 400. It was estimated that it would be possible to provide employment to a maximum of 1000 people per week. Employing any more people depended on securing additional loans for intervention projects. The unemployed were hired on a temporary basis, for a period of at least 4 weeks. The daily rate of pay was set at 3 zlotys $^{37}$. However, the money earned in this way was not paid directly to the unemployed. It was used as a kind of repayment for the social benefits, and this money was paid to the Local Unemployed Assistance Fund (Lokalny Fundusz Pomocy Bezrobotnym) which in turn provided the aid as needed.

During the winter of 1933/34 the unemployed and their families were entitled to receive $2 \mathrm{~kg}$ of bread per person (over 2 years old) per week, and:

- potatoes (in winter time): single individuals received around $65 \mathrm{~kg}$; small families - around $400 \mathrm{~kg}$, medium-sized families - around $520 \mathrm{~kg}$, large-sized families - around $650 \mathrm{~kg}$.

- coal (per month): single individuals received around $65 \mathrm{~kg}$; small families - around $130 \mathrm{~kg}$, medium-sized families - around $160 \mathrm{~kg}$, largesized families - around $200 \mathrm{~kg}$.

- firewood (per month): medium-sized families received 1/8 stère (roughly equivalent to $1 / 8 \mathrm{cu}$. metre), large-sized families - around $1 / 4$ stère.

Additional benefits included milk, with children under 1 year receiving 1 litre per day and children between 1 and 4 year receiving 1/2 litre daily. Those who were not receiving bread (food) coupons were able to avail themselves of soup kitchens which provided lunches of 3/4 litres of soup

37 Protokót z konferencji w sprawie odpracowania świadczeń z dnia 28.02.1934 r. (transcript), APP, City of Poznań Records, ref. 7239, p. 36-40. 
and $100 \mathrm{~g}$ of bread. At schools children of the unemployed were entitled to lunches comprising 1/2 litre of soup and $150 \mathrm{~g}$ of bread (in 12 schools meals were provided in this way to some 3500 children). Moreover, unemployed individuals were receiving clothing coupons and cash coupons (to be used to purchase foodstuffs) with single people entitled to coupons worth 0,50 zloty (per week), small families receiving coupons worth 1 zloty, medium-sized families 1,50 zlotys and large-sized families 2 zlotys ${ }^{38}$.

The resources earmarked for social assistance were nevertheless pretty modest. This was especially true in the winter of 1935/36, which had tragic consequences as the city authorities had to organise campaigns to collect money and clothing for the unemployed. In February 1936 a special charity "Week of assistance for the unemployed" was organised with money donations being collected on different days by members of different professions, including physicians, lawyers, teachers, businessmen, sales people and others. Original expectations were that some 200,000 zlotys would be collected. In the event, the collected donations totalled only just above 25,000. Towards the end of February and in early March 1936 another "Week to collect clothing and donations in kind for the unemployed" was organised. This charity drive succeeded in collecting clothing and footwear worth 50,000 złotys. The army became actively involved in this charity initiative as well, providing field kitchens and donating food ${ }^{39}$.

The Citizen's Committee to Combat Unemployment in the City (Miejski Obywatelski Komitet do Walki z Bezrobociem), headed by Erwin Więckowski (the interim Mayor of Poznań), came to the conclusion that such campaigns organized ad hoc to provide aid to the unemployed failed to achieve the expected results. Work started to organise more regular campaigns with aid provided by residents of the city. One such idea was to provide or fund meals for the unemployed. Families who were in a position to offer such aid were to provide one meal per week for an unemployed person. This initiative, however, failed to gain support among the residents of Poznan. Another type of aid for the unemployed was the move in 1936 to introduce a fixed charge or fee to fund aid for the unemployed. The following fixed rates were established depending on pay received:

- up to 160 zlotys per month - 0,25\%;

- between 160 and 350 per month - 0,50\%;

- between 350 and 600 per month - 1\%;

38 Pomoc doraźna dla bezrobotnych, Nowy Kurier z dnia 4.02.1934, R.45, No. 27, p. 11.

39 E. Makowski, Bezrobotni w Poznaniu w latach 1929-1939, Part II, W okresie pokryzysowym..., p. 63-64. 
- between 600 and 1200 per month - 11/2\%;

- between 1200 and 2500 per month - 2\%;

- over 2500 per month - 5\%.

Respective rates were also set for companies and businesses, traders, craftsmen and real estate owners ${ }^{40}$.

There were also attempts to make the unemployed more self-dependent by establishing garden allotments using the land owned by the city. In this way several hundred allotments were established which were then handed over to the unemployed. This allowed the unemployed to grow vegetables for their own needs, with the city providing seeds, seedlings, manure and seeds as well as specialist training and supervision by the Municipal Gardens' staff. There were two types of allotments established and organised by the municipal authorities. One type were residential allotments which were used by the city to build huts for the homeless (Naramowice, Krzyżowniki, Aleja Bałtycka). The other type were allotments without the possibility of constructing any such shelters. Depending on their purpose, the allotments differed in size.

Table 2. The list of allotments assigned to the homeless and the unemployed (as on September 1937).

\begin{tabular}{lccc}
\hline \multicolumn{1}{c}{ Location } & $\begin{array}{c}\text { Number of allot- } \\
\text { ments }\end{array}$ & Average size $\left(\mathrm{m}^{2}\right)$ & $\begin{array}{c}\text { Total area } \\
\left(\mathrm{m}^{2}\right)\end{array}$ \\
\hline Naramowice & 175 & 800 & 150,000 \\
\hline Krzyżowniki & 100 & 800 & 80,000 \\
\hline Al. Bałtycka & 141 & 600 & 84,600 \\
\hline Fort V & 40 & 520 & 20,800 \\
\hline Al. Krakowska & 144 & 100 & 14,400 \\
\hline Świerczewska Street & 96 & 100 & 9,600 \\
\hline Górna Wilda Street & 12 & 200 & 2,400 \\
\hline Dolna Wilda Street & 18 & 60 & 1,080 \\
\hline Za Bramą Warszawską & 110 & 400 & 44,000 \\
\hline Starołęka & - & - & 5,000 \\
\hline Total & 836 & - & 411,880 \\
\hline
\end{tabular}

Source: Wydział Opieki Społecznej do Dyrektora Ogrodów Miejskich z dnia 29.09.1937, AAP, City of Poznań Records, ref. 7239, p. 218.

40 A leaflet published by Citizen's Committee to Combat Unemployment in the City (1936), APP, City of Poznań Records, ref. 7239, p. 133. 
In the years that followed, the City continued to look for suitable land that could be developed and turned into allotments for the unemployed. Hence table 2 shows the 5,000 sq. metre plot of land in Starołęka which, it would appear, was yet to be divided into individual allotments. By 1937 more land was secured near Al. Krakowska in the Dębiec area (7 ha), and in 1938 another plot in Kopanina ( 3 ha) was added. The overall number of the unemployed people who were making use of such allotments in 1937 was estimated at 1,797. In February 1938 Artur Matuszewski, head of the Poznań Province (Wojezwoda Poznański), tried to motivate heads of powiats and town mayors to step up efforts to organise and provide allotments for the unemployed in the belief that providing a plot of land to grow food produce for people's own needs was the best method available to alleviate the impact of unemployment ${ }^{41}$.

\section{HOUSING IN POZNAŃ AND ACCOMMODATING THE HOMELESS IN THE FORMER PWK EXHIBITION GROUNDS}

In the days preceding the great economic crisis the accommodation standards for the blue collar worker in Poznań was pretty high. Władysław Czarnecki recalls that "in Poznań it was normal for a working class family to occupy a 3-room flat with a kitchen and a bathroom" ${ }^{42}$. When compared with other cities in Poland, the overall housing conditions in Poznan were much better. Single-room flats accounted for $14.3 \%$, with two-room flats constituting $29.2 \%$, and three-room flats $25.4 \%$. In the architect's view those were the best housing conditions among the Polish cities, but the situation was still bad b3 $^{4}$.

In the 20-year period between the world wars Poznan struggled to solve many serious housing problems. First and foremost, there was a lack of cheaper, low standard apartments and lack of suitable accommodation for the homeless. Since the city's resources that could be used for new con-

${ }^{41}$ Wojewoda Poznański do Starostów powiatowych i Prezydentów miast, dated 15.02.1938 r. APP, City of Poznań Records, ref. 7239, p. 197; Wstępne sprawozdanie z organizacji ogrodów dziatkowych przygotowane przez Dyrektora Ogrodów Miejskich of 17.03.1938, ibidem, p. 198.

42 Wł. Czarnecki, op. cit, p. 21.

43 Ibidem, p. 188-189. 
struction projects were limited, and the housing problems were becoming even more acute as the economic crisis deepened, a decision was taken to adopt an interim solution by providing dwellings in the shape of garden huts or sheds to provide shelter to those in need. "Make it easy, make it fast and make it cheap, only to secure some place of abode for the homeless, could be the motto of this project [to build the huts in the Zawady area]" ${ }^{44}$.

After the World War I, during the post-war economic crisis, the building and construction industry was in stagnation. It was not until 1923 that this crisis was finally overcome and Poznan saw its building trade return to the path of recovery which lasted until early $1930 \mathrm{~s}^{45}$. The investments in connection with the Polish National General Exhibition were definitely a factor which provided a much needed boost. However, this upturn in demand in the building and construction sector also attracted more migrants into the city, the fact which only aggravated the already difficult situation in housing. Figures in table 3 below indicate a particularly strong influx of new people into the city which lasted until 1931.

Table 3. Increase in the population of Poznań due to the external influx of people in 19271937 (before and after being verified by the 1931 census).

\begin{tabular}{llllllllllll}
\hline \multicolumn{1}{c}{ Year } & 1927 & 1928 & 1929 & 1930 & 1931 & 1932 & 1933 & 1934 & 1935 & 1936 & 1937 \\
\hline $\begin{array}{l}\text { Population } \\
\text { increase due } \\
\text { to influx of } \\
\text { people }\end{array}$ & 7980 & 9366 & 11079 & 2883 & 1820 & - & - & - & - & - & - \\
\hline $\begin{array}{l}\text { Population } \\
\text { increase (in- } \\
\text { flux of people } \\
\text { as confirmed } \\
\text { by the 1931 } \\
\text { census) }\end{array}$ & 5760 & 5828 & 5817 & 5629 & 4343 & 1170 & 754 & 1571 & 3901 & 3951 & 2514 \\
\hline
\end{tabular}

Source: Rocznik statystyczny stołecznego miasta Poznania za lata 1929-1932, Poznań 1932, p. 44; Rocznik statystyczny stotecznego miasta Poznania za lata 1933-1934, Poznań 1935, p. 40; Rocznik statystyczny stołecznego miasta Poznania za 1936-1937, Poznań 1938, p. 42; Rocznik statystyczny stołecznego miasta Poznania za 1937-1938, Poznań 1938, p. 42.

44 Ibidem, p. 63.

45 J. Pazdera (Ed.), Atlas architektury Poznania, Poznań 2008, p. 67. 
The pool of available accommodation was growing at a much slower rate compared to the influx of people and the growth of population. Due to the lack of availability of loans for the general public, a large proportion of the burden and overall responsibility to provide cheap accommodation for the least affluent residents of Poznan rested with the municipal authorities.

In the 1923-1925 period a total of 124 flats were built in Poznań. The council flats complex near Nowe Zagórze Street was built in 1924-25. It was the first housing development built in Poznan after the end of the World War I. The flats comprised a single room with a kitchen which could also double as a bedroom. Lavatories were provided on staircases ${ }^{46}$. In 1925 the city came with plans for a working class colony in the Górczyn area. It was another municipal investment project aimed at easing the pressing problem of lack of dwellings for the lowest earning labourers ${ }^{47}$.

From 1926 there was an upturn in the housing construction sector. It was then that the estate in Górczyn, the blocks of flats in Wały Jagiełly and in Rybaki Street and a residential building in Głogowska Street were all built $^{48}$. In connection with the work to stage the PWK Exhibition the municipal authorities took several measures to increase the number of available flats, especially smaller dwellings. In 1926 a large residential building designed by Władysław Czarnecki was built on the land near Rolna, Wspólna, Łanowa and Tokarska streets. This complex offered a total of 276 flats, each comprising a lobby, a kitchen, a pantry, a lavatory and two rooms, with some flats even equipped additionally with a third small room $^{49}$. When calculating the cost of using this accommodation by future tenants it was accepted in advance that the city will need to subsidise $50 \%$ of the rent because it was clear the tenants would not be able to pay the full rent from their own resources ${ }^{50}$. In another move, tenement buildings were built in Słowackiego Street to accommodate the employees of PEK, the Poznań Electric Railway Company ${ }^{51}$.

Władysław Czarnecki also designed another residential hut estate or colony located in the Zawady area and built in October and November

\footnotetext{
46 Ibidem, p. 216.

47 Ibidem, p. 82.

48 Wł. Czarnecki, Wspomnienia architekta, Vol. 1 1895-1930, Poznań 2005, p. 86-87.

49 Ibidem, p. 90.

50 Wypis z protokotu posiedzenia Rady Miejskiej z 10.04.1929, APP, City of Poznań Records,

${ }^{51}$ Wł. Czarnecki, Wspomnienia architekta..., p. 102.
} ref. 4650, p. 115. 
1928. It was meant to be an interim measure aimed to help ease the housing shortage in Poznan in the short term. This estate comprised 9 singlestorey buildings which housed a total of 63 flats. Those dwellings comprised a kitchenette with a room as well as a pantry and a lavatory. The entry from outside lead straight into a small ante-room. The buildings were constructed from pressed boards of compressed reeds tied together by means of wire. Those boards were nailed to a wooden structural framework, and the walls were subsequently plastered over. The design was very simple; construction work proceeded apace, and the overall effect was satisfactory. The buildings constructed in this way were tidy and offered good insulation. Additionally, care was taken to provide playgrounds for children ${ }^{52}$.

In another development in the Zawady area, a complex of residential buildings for workers and labourers was built in 1935-39. Located in Zawady Street 2/8 and Chlebowa Street 1/7, this complex comprised three four-storey buildings with outside staircases and galleries leading to individual flats. The 34 and $38 \mathrm{~m}^{2}$ flats were designed to accommodate a family of five and offered a room, a kitchen which doubled as a bedroom and a lavatory ${ }^{53}$.

Table 4. Total increase in the number of flats in Poznań in the 1927-1937 period.

\begin{tabular}{cccccccccccc}
\hline Year & 1927 & 1928 & 1929 & 1930 & 1931 & 1932 & 1933 & 1934 & 1935 & 1936 & 1937 \\
\hline $\begin{array}{l}\text { Number } \\
\text { of flats }\end{array}$ & 424 & 572 & 448 & 1120 & 1119 & 853 & 1023 & 889 & 925 & 1712 & 1627 \\
added & & & & & & & & & & & \\
\hline
\end{tabular}

Source: Rocznik statystyczny stołecznego miasta Poznania za rok 1928, Poznań 1930, p. 22; Rocznik statystyczny stołecznego miasta Poznania za lata 1929-1932, Poznań 1932, p. 21; Rocznik statystyczny stołecznego miasta Poznania za lata 1933-1934, Poznań 1935, p. 21; Rocznik statystyczny stołecznego miasta Poznania za lata 1934- 1935, Poznań, 1935, p. 22; Rocznik statystyczny stołecznego miasta Poznania za lata 1935-1936, Poznań 1936, p. 31; Rocznik statystyczny stołecznego miasta Poznania za lata 1936-1937, Poznań 1938, p. 24; Rocznik statystyczny stołecznego miasta Poznania za lata 1937-1938, Poznań 1938, p. 24.

The above table shows that the largest numbers of flats were added in 1930-31 and 1936-37. The above figures alone present a fairly optimistic picture, but they must be viewed in the context of the estimated overall deficit of dwellings in order to be able to assess the true magnitude of the problem.

\footnotetext{
52 Wł. Czarnecki, To był też mój Poznań..., p. 63.

53 Atlas architektury Poznania..., p. 328.
} 
Table 5. The calculated deficit of flats in Poznań in 1927-1937 (before and after validation against the results of the 1931 census).

\begin{tabular}{|c|c|c|c|c|c|c|c|c|c|c|c|}
\hline Year & 1927 & 1928 & 1929 & 1930 & 1931 & 1932 & 1933 & 1934 & 1935 & 1936 & 1937 \\
\hline $\begin{array}{l}\text { Calculated } \\
\text { deficit of } \\
\text { flats }\end{array}$ & 7579 & $\begin{array}{c}8796 \\
(7736)^{*}\end{array}$ & 9071 & 9697 & 9951 & 10570 & 10992 & 11671 & 12656 & - & - \\
\hline $\begin{array}{l}\text { The defi- } \\
\text { cit as con- } \\
\text { firmed by } \\
\text { the } 1931 \\
\text { census.** }^{*}\end{array}$ & - & - & - & - & 3858 & 4472 & 4899 & 5578 & 6372 & 6445 & 6644 \\
\hline
\end{tabular}

Source: Rocznik statystyczny stołecznego miasta Poznania za rok 1928, Poznań 1930, p. 24; Rocznik statystyczny stotecznego miasta Poznania za lata 1929-1932, Poznań 1932, p. 24; Rocznik statystyczny stotecznego miasta Poznania za lata 1933-1934, Poznań 1935, p. 21; Rocznik statystyczny stołecznego miasta Poznania za lata 1934-1935, Poznań 1935, p. 23; Rocznik statystyczny stołecznego miasta Poznania za lata 1935-1936, Poznań 1936, p. 31; * Rocznik statystyczny stołecznego miasta Poznania za lata 1929-1932, Poznań 1932, p. 24; ** Rocznik statystyczny stołecznego miasta Poznania za lata 1936-1937, Poznań 1938, p. 25; Rocznik statystyczny stołecznego miasta Poznania za lata 1937-1938, Poznań 1938, p. 25.

Despite this steady increase in the number of flats and other accommodation available, the housing deficit continued to intensify all the time. It is estimated that in 1938 there was a deficit of 8,173 flats in Poznan (a total of 6,644 flats needed as per statistical data for that time, plus the number of families accommodated in shelters for the homeless, 1429 in total; plus families staying in overnight shelters, estimated at around 100) ${ }^{54}$.

As the economic crisis was becoming more and more evident, the homelessness problem in the city was becoming more acute. Despite a slight dip reported in 1932/33, the number of the homeless in Poznań in the 19291939 period was effectively showing continuous increase, from 81 homeless families (322 people, including 127 children) in 1928/29, to 1429 families (6,557 people, including 3,362 children) in 1937/3855.

A new shelter for the homeless at no. 2, św. Wincentego Street (Zawady) was built from the city resources in 1929-30. In terms of architectural design (by Władysław Czarnecki) and in terms of overall concept for this type of institution, the building was modelled on similar designs seen in Germany ${ }^{56}$. The shelter provided a total of 100 places for men and

${ }^{54}$ H. Maciejewski, op. cit., p. 231.

55 Ibidem, p. 228

56 Atlas architektury Poznania..., p. 312. Currently the building is used as the Infectious Diseases Ward, the City Hospital. 
100 places for women. At the time it was regarded as a model solution for the whole of Poland. Delegations from other cities frequently visited on fact-finding missions to see for themselves the solutions that had been adopted in Poznan ${ }^{57}$.

During the time of the economic crisis, due to unemployment, people's lack of resources to support themselves and general lack of accommodation, it was becoming increasingly more common for people to seek accommodation as lodgers. It is estimated that in 1931 some $25.5 \%$ apartments in Poznań were used by lodgers, and as much as $32.7 \%$ of the population became lodgers. It was a high percentage. The number of single-room flats occupied by two or more households (families) reached 1,131 (with a total of 7,402 living in this way). The number of two-room dwellings occupied by three or more households (families) reached 551 (3,391 people) ${ }^{58}$.

This shortage of accommodation and the lack of money to pay the rent meant that eviction became quite commonplace, the trend which contributed to the number of the homeless even more. Many people were desperate to find even the meanest of shelters. Sections of staircases and sections of large drive-through gates in tenement buildings in the Old Town used to be converted to build additional accommodation, and landlords asked lodgers to pay real money for the "privilege" of staying in those makeshift "flats" 59.

The city authorities knew full well the extent of the crisis on the housing and accommodation market. In another attempt to ease the situation, a decision was made to reduce the rents in council flats. It was hoped this move would make it easier for tenant to pay their bills and will help to reduce the number of compulsory evictions.

Despite all those attempts the number of households unable to pay even the lowest of rents was on the increase. Unregulated settlements or estates which attracted squatters started to appear on the vacant plots or undeveloped land around the city. One such place has been described in Maria Rataj's memoirs:

And there you saw, as if clinging to one another, an array of shacks, huts, sheds. Fashioned from wagons or parts of carts, from bent bits of metal sheets taken from advertising boards, they were made from cardboard, from planks, clay, gypsum or bits of turf. Bits of glass glistened here and there doubling as windows. It was an eerie

57 Wł. Czarnecki, To był też mój Poznań..., p. 62.

58 H. Maciejewski, op. cit., p. 226-227.

${ }_{59}$ M. Rataj, Bezdomni [in:] T. Kraszewski, T. Świtała (Ed.), Poznańskie wspominki z lat 1918-1939, Poznań 1973, p. 115. 


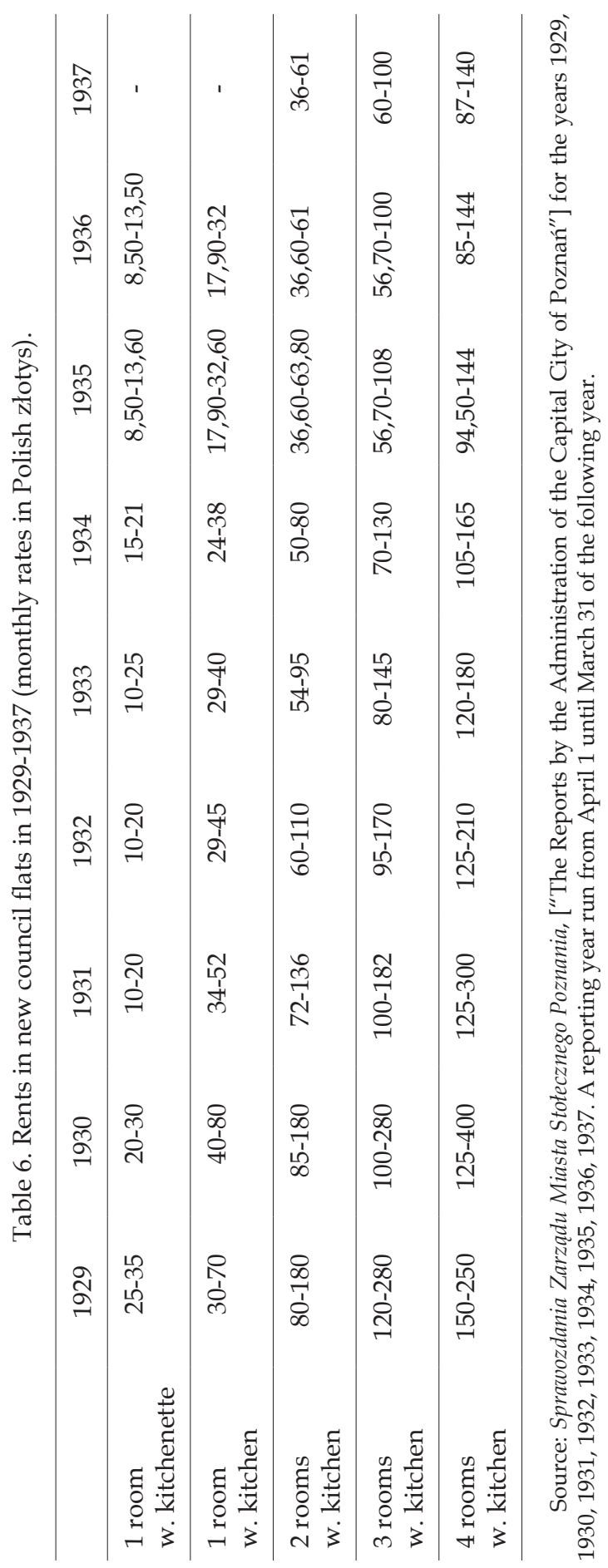


but also a fantastic sight. It appeared as if we have been taken into a land taken from a sinister fairy tale where children of giants tried to build a settlement on a water bank modelled on settlements in which humans lived. But you would be wrong to think that those caricature structures had anything funny about them ${ }^{60}$.

Overcrowded homeless shelters and the growing number of the homeless struggling to find a place to live persuaded the city authorities to arrange more temporary dwellings using the buildings vacated after the PWK exhibition had closed. Those shelters, housed in the former exhibition halls, were treated as shelters. In terms of organisation they reported to the Department of Social Care. In all, a total of 13 buildings were redeveloped in this way. Vacated exhibition halls were converted into makeshift dwelling places. The space would be divided into compartments by means of wooden partitions, with each such compartment being occupied by a single family.

Maria Rataj left a description of such "dwellings" in the former PWK buildings in her writings. On the outside she saw it as "a hall with broken windows, covered with rags of different colours" ${ }^{\prime \prime 1}$. Inside the place looked no better:

We entered the hall. What hit us first was some sort of smell emanating from a mixture which could be rutabaga or cabbage perhaps but not quite. The hall was huge. It was divided into compartments, almost like cages four by six square metres large, using wooden planks. These partitions were two metres high, and there was nothing on top to cover the compartments. And overhead there were pipes and tubes running in various directions and connected to heating stoves, and secured with wires. Some of those pipes were red-hot from the fire, and it was almost strange that nothing caught fire as a result ${ }^{62}$.

The conditions were very difficult with residents complaining about the damp, the cold and the overwhelming stuffy and smelly air. Those conditions led to many diseases, especially among children ${ }^{63}$. Residents were required to pay the rent all the same, and in 1932 this rent was set at 4 złotys per month for unemployed families, and at 10 złotys per month for families whose members had a job. It must be stressed, however, that the majority of tenant were jobless ${ }^{64}$. At the height of the period when

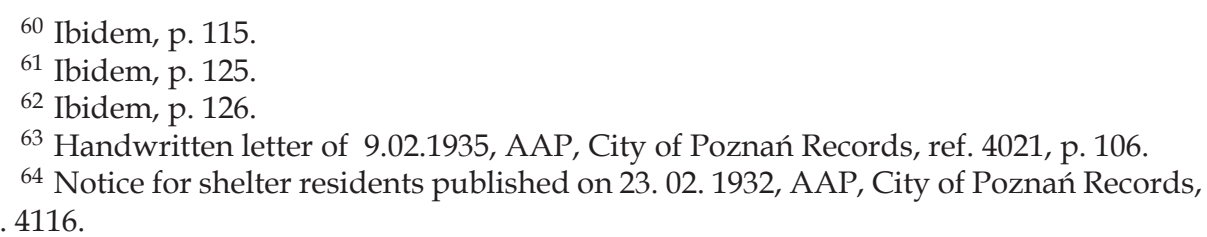
ref. 4116 . 
Table 7. Overall numbers of the homeless accommodated in Poznań shelters in 1929-1937

\begin{tabular}{|c|c|c|c|c|c|c|c|c|c|}
\hline & 1929 & 1930 & 1931 & 1932 & 1933 & 1934 & 1935 & 1936 & 1937 \\
\hline 11, św. Rocha Street & 92 & - & - & - & - & - & - & - & - \\
\hline $\begin{array}{l}\text { 8, Knapowskiego } \\
\text { Street }\end{array}$ & 33 & - & - & - & - & - & - & - & - \\
\hline 1, św. Rocha Street & 119 & 90 & 82 & 88 & 99 & 84 & 88 & 59 & 54 \\
\hline $\begin{array}{l}\text { 5, Wenecjańska } \\
\text { Street }\end{array}$ & 142 & 158 & 75 & 100 & 64 & 61 & 13 & 12 & 11 \\
\hline $\begin{array}{l}\text { św. Antoniego St. } \\
\text { (Starołęka) }\end{array}$ & 16 & 18 & 18 & 16 & 20 & 22 & 19 & 24 & 20 \\
\hline $\begin{array}{l}\text { 88, Chociszewskiego } \\
\text { Street }\end{array}$ & - & 112 & - & - & - & - & - & - & - \\
\hline $\begin{array}{l}89 \text {, Chociszewskiego } \\
\text { Street }\end{array}$ & - & 97 & - & - & - & - & - & - & - \\
\hline Huts, Główna Street & - & 254 & - & - & - & - & - & - & - \\
\hline $\begin{array}{l}\text { In the exhibition } \\
\text { grounds }\end{array}$ & - & - & 1335 & 938 & 1498 & 1528 & 628 & - & - \\
\hline $\begin{array}{l}\text { Huts, za Bramą } \\
\text { Warszawską }\end{array}$ & - & - & 459 & 465 & 477 & 492 & 473 & 490 & 478 \\
\hline 9, Krańcowa Street & - & - & - & - & 55 & - & - & - & - \\
\hline Droga Urbanowska 1 & - & - & - & - & - & 644 & 632 & 632 & 635 \\
\hline Naramowice Estate & - & - & - & - & - & 413 & 891 & 1029 & 1001 \\
\hline $\begin{array}{l}\text { 35, Dolna Wilda } \\
\text { Street }\end{array}$ & - & - & - & - & - & 79 & 38 & 82 & 86 \\
\hline Hut, Smolna Street & - & - & - & - & - & 24 & 24 & 25 & 15 \\
\hline Forts & - & - & - & - & - & - & 960 & 958 & 950 \\
\hline Bałtycka Street estate & - & - & - & - & - & - & 252 & 606 & 661 \\
\hline $\begin{array}{l}\text { Huts in } \\
\text { Świerczewska Street }\end{array}$ & - & - & - & - & - & - & 447 & 458 & 455 \\
\hline Piotrowo & - & - & - & - & - & - & - & 110 & 112 \\
\hline Górna Wilda Street & - & - & - & - & - & - & - & 53 & 55 \\
\hline Krzyżowniki estate & - & - & - & - & - & - & - & 515 & 593 \\
\hline $\begin{array}{l}\text { Private accommo- } \\
\text { dation }\end{array}$ & - & - & - & - & - & - & - & 240 & 356 \\
\hline Krakowska estate & - & - & - & - & - & - & - & - & 665 \\
\hline Kopanina estate & - & - & - & - & - & - & - & - & 550 \\
\hline Total residents: & 402 & 728 & 1968 & 1607 & 2213 & 3347 & 4465 & 5942 & 6657 \\
\hline
\end{tabular}

Source: Sprawozdania Zarządu Miasta Stołecznego Poznania for the years: 1929, 1930, 1931, 1932, 1933, 1934, 1935, 1936, 1937. A reporting year run from April 1 until March 31 of the following year. 
the former PWK buildings were used, in the 1933-1934 period, there were around 1,500 people living there (see table 7), including numerous families with children. Then, not far from the former PWK buildings, a township of shacks huts and shelters grew next to the Al. Reymonta thoroughfare, built of whatever "material was at hand". The municipal authorities could not tolerate such a violation of land use and order compulsory demolition of those shelters ${ }^{65}$.

The homeless were also being accommodated in buildings remaining from former forts and in sheds or huts built by the city authorities. However, there was a pressing need to find a new solution. The former exhibition halls clearly were not suited for use as living quarters. Also, the city authorities had other plans to redevelop the former exhibition grounds, with plans being drawn to establish a new park (which became the Kasprowicza Park). Gradual liquidation and demolishing of the former exhibition buildings started as residents were being transferred to other places of accommodation, such as forts, huts and newly-established residential allotments for the homeless. The figures in table 7 indicate that the city authorities undertook measures to transfer the homeless from interim, provisional shelters to the accommodation which offered a slightly higher standard of living, mainly the above-mentioned huts and residential allotments. A sizeable group of the homeless was transferred to former forts. It would be difficult to argue that forts offered better living conditions. However, even in the case of forts there were attempts to provide the homeless with garden allotments of some sort to allow the resident to grow some vegetables for their own use.

\section{COMMUNITY GARDEN ESTATES AS AN ATTEMPT TO PROVIDE DWELLINGS FOR THE HOMELESS AND THE UNEMPLOYED IN POZNAŃ}

Community gardens based on a system of allotments began to be established in Poznań from 1906. The K. Marcinkowski Community Garden located in what is now the borough of Grunwald was established at the time. A further four such community gardens were established by 1920,

65 Drugie "Smutne miasteczko" w budowie, "Kurier Poznański", published on 10.08.1935, Vol. 30, No. 363, p. 6. 
with another nine added in the 1920s. By 1937 Poznań boasted a total of 22 community gardens. During the time of the economic crisis, but also in the later period, until the World War II those gardens were used not only for recreation, but they also provided some vital living accommodation and had some economic significance. They provided shelter to the jobless and the homeless, and they provided an opportunity of securing at least some sustenance for residents who were able to grow some crops ${ }^{66}$.

One of the solutions developed to resolve the shortage of housing in Poznan was the scheme to establish the so-called "community garden estates". They were located on the outskirts of the city and were used to provide accommodation for the homeless Designed by Jan Zbijewski, those living quarters were built using simple and cheap building materials. Such estates were being established throughout the 20 -year period between the world wars. The estate at Jarzębowa Street is a case in point. In 1934 another such estate was built in Naramowice. This estate was regarded as a good example of how to try to tackle the housing shortage problem and to resolve the pressing issue of homelessness. The scheme was entered for presentation at a conference on housing reform in Prague in 1934 as a good example of a positive remedy for a housing shortage ${ }^{67}$.

The instigator behind the idea to build purpose-built residential garden huts on community garden grounds or allotments was Władysław Marciniec, head of the Municipal Gardens ${ }^{68}$. It must be said, however, that an important reason for this initiative was the desire to put an end to the lawless use of vacant city land property commonly used to build shelters without any required permissions. The homeless and the unemployed who had seriously defaulted on paying their rent and who were subsequently evicted from their lodgings, went on to build primitive shelters, occupy vacant properties to turn them into accommodation and converted garden huts or sheds into dwellings. Unlike the living quarters provided in the former PWK Exhibition buildings, any such lawless accommodation remained beyond any control of the municipal authorities.

Such illegal estates were created, among others, in the former exhibition buildings that had not been demolished around the so-called "PWK

66 W. Deja, Ogrody działkowe Poznania na tle warunków przyrodniczych miasta, KMP no. 3, 1983, p. 58.

${ }^{67}$ H. Grzeszczuk-Brendel, Architektura $i$ budownictwo Poznania w pierwszej połowie XX wieku [in:] Architektura i urbanistyka Poznania w XX wieku, T. Jakimowicz (Ed.), Poznań 2005, p. 102.

${ }^{68}$ Wł. Czarnecki, To był też mój Poznań, p. 202. 
fun fair" ${ }^{\prime \prime}$, in the former military fort installations, in warehouses and in huts located on the land near Bułgarska Street, in the community gardens for the unemployed in the Górczyn area (made available by the local parish), near Główna Street and in other areas used for allotments ${ }^{70}$. Because it was not possible to radically eradicate this trend because the city had to provide some kind of accommodation for the homeless, it was decided to use for this purpose the section of the poorest quality land owned by the city in Naramowice, where farming was potentially least viable. The plan for a 170-home estate with 800 sq. metre allotments, with a children's playground, and with space for a nursery school, a school and after-school care facility, was approved by the City Council. This concept was deemed to be the most suitable considering the city's resources available at the time. The cost of home and plot was established at 2,000 zlotys. The rent was set at 12 zlotys per month with the unemployed being given the opportunity to settle the rent by making themselves available for work for various municipal departments and institutions, mainly the Municipal Gardens. Ownership of those homes and allotments was to be transferred to their residents after around 20 years, i.e. after the cost of building them had been recouped by the city ${ }^{71}$. This was to motivate the residents to look after the land and the facilities that have been leased to them, and to encourage them to try to improve the standard of the dwellings using their own resources. The Estate Construction Committee was appointed with the following membership: Kazimierz Motyliński (Head of Department of the Social Care), Oskar Pohlman (Head of the Housing Department), J. Zaus (Head of the Department of Construction and Civil Engineering Supervision), Władysław Czarnecki (Head of Urban Development) and W. Marciniec (Director, the Municipal Gardens) ${ }^{72}$.

It was decided that residents would receive support in the shape of seeds and seedlings, with additional training on how to grow and manage a garden adjacent to a house in order to enable them to grow extra food for their own needs. The idea was to make such resident more self-dependent and less reliant on the social care and social services.

69 Wł. Czarnecki estimated that some 1,700 may have lived on the so-called Fun Fair grounds, see: Wł. Czarnecki, To był też mój Poznań..., p. 201; it appears, however, that his estimates include also the residents who lived legally in the former exhibition halls with the permission from the Department of Social care, but not the people who built their makeshift shelters illegally.

${ }^{70}$ Wł. Czarnecki, To był też mój Poznań..., pp. 201-202.

${ }^{71}$ Ibidem, p. 203.

${ }^{72}$ Ibidem, pp. 203-204. 
Wooden homes were designed especially for this homeless estate in Naramowice. There were two types of homes. The type I was a 30 sq. metre home comprising a (bed)room with a kitchenette and a small veranda. Type II was a 31.76 sq. metre home comprising a (bed)room with a kitchenette, a veranda, a hall, a pantry and a small cellar. All homes were heat-insulated and were considered as ass-season lodgings. In the first stage of completion, a total of 20 type I homes and 50 type II homes were built. There was also one utility building for each four homes. Such utility buildings comprised separate lavatories for each allotment, firewood lockers, pigsties and chicken pens (for type II homes the actual arrangement of the utility building was left for the lodgers to decide). The cost of constructing the homes was from around 1,600 to around 2,126 zlotys, depending on the design ${ }^{73}$.

It appears that not everyone was happy, however. There was a protest against the proposed Naramowice estate coming from the local parishpriest. The clergyman was concerned about the potential influx of people with questionable reputations, many of whom had a history of theft convictions, and drunks. The parish-priest, however, did not have any influence over the decisions made by the municipal authorities. In the event, it turned out that the residents behaved themselves and did not bring disrepute to the local parish. After all they did have a clear objective in their lives. They were no longer homeless, and they identified themselves with the new place of abode. The estate population rapidly expanded an in a short time reached 1,500 . The local school established at the estate was doing very well under the leadership of Czesław Hawliczek, the head teacher. There was also a local scout unit, the No. 6 Scout Troop, which went on to become one of the best scout units in Poznan. One could say that this social experiment ended in success. Other cities would send delegations on fact-finding missions to Poznań to view the results. The designs for allotments and accommodation were exhibited at a show organised by the Union of Garden Allotment Associations (Zwiazek Towarzystw Ogrodów Dziatkowych). Similar investment projects were subsequently completed in the towns of Szamotuły, Tczew, Wąbrzeźno and Ostrów.

There was also a concept of another estate in the Naramowice area (designed by M. Spychalski), intended for unemployed gardeners. 2 hectare allotments were planned, and future occupants were to grow vegetables and flowers. The overall concept was approved by the City Council.

73 Sprawozdanie techniczne $z$ budowy osiedla dla bezdomnych w Naramowicach za czas 28.10.1933 - 31.05.1935, APP, City of Poznań Records, ref. 7239, p. 72-77. 
However, due to the poor soil quality which would make any crops nonviable, this particular project was abandoned ${ }^{74}$.

The scheme adopted for Naramowice became an inspiration to build more estates. One such estate was planned in Krzyżowniki, comprising a total of 120 plots, each one around 800 sq. metres in size. The semi-detached homes built here were masonry structures, much stronger and better built than the homes seen in Naramowice.

More estates for the homeless and the unemployed were established in the Dębiec and Świerczewo areas. They consisted of single-storey huts, with each segment large enough to house four flats comprising one room with a kitchen and a storage room. Overall design of this estate was the work of the City Urban Planning Office ${ }^{75}$. As a result, 144 new allotments were established, with further 96 in the Świerczewo area. The allotments were much smaller $\left(75-100 \mathrm{~m}^{2}\right)$ compared to the allotments seen in Naramowice and Krzyżowniki, and were used as vegetable gardens for the benefit of the residents living in hut estates ${ }^{76}$.

Settlements or estates set up specifically for the homeless also became a focus of interest of sociologists. The guest speaker at a meeting of the Polish Sociology Institute held in May 1937 was Hipolit Maciejewski, the caretaker of the Krzyżowniki estate. He was invited by Professor Florian Znaniecki to give a talk on the residents of his estate ${ }^{77}$. The actual paper read by the caretaker at that session has been preserved in the State Archives in Poznan ${ }^{78}$ and is now an interesting and unique source of information about the relations among the residents at the time. There were 99 tenant families at the estate ( 115 males, 112 females and 289 children). Only three persons in that group had full-time jobs, with a further 17 people temporarily employed by the Labour Fund for intervention jobs. The caretaker has classified the unemployed residents into three categories. The first group were what he calls the "true unemployed", i.e. those who had lost their jobs as a result of the economic crisis and who were trying to find alternative employment at all cost. Those people accounted for some $70 \%$ of the whole community. The second group were the chronic or, in his words, "pro-

${ }^{74}$ Wł. Czarnecki, To był też mój Poznań...., pp. 205-208.

75 Atlas architektury Poznania..., p. 155.

76 Osiedla i baraki dla bezdomnych w Poznaniu (typescript), APP, City of Poznań Records, ref. 7239, p. 148-149.

77 Polski Instytut Socjologiczny do Wydziału Opieki Społecznej, datek 4.05.1937, APP, City of Poznań Records, ref. 4151, p. 111.

78 APP, City of Poznań Records, ref. 4151, p. 114-117. 
fessional" unemployed, i.e. the individuals who evaded work, had a penchant for begging and who preferred to rely on social care and charity organisations. The third category were youths whom he described as being lazy, unwilling to work, with no qualifications and growing accustomed and increasingly more dependent on the social care system.

There was also another type of polarity among the unemployed residents, namely the division between the more and the less resourceful individuals, the more and the less hard-working people. There were residents who made the best possible use of the allotments they had been given, by planting trees and shrubbery, by breeding poultry and pigeons. Those were the people who did their best to use the opportunity they had been given to improve their lot and material status. And then there were those who were content just to survive in the hope that one day their lot would somehow improve. The former scorned the latter, and the latter envied the former which lead to quarrels and conflicts among neighbours. The terms of occupation, the structure of that community was very varied. Out of the 98 main allotment tenants there were 53 labourers without a specified profession (unskilled labourers), and the rest were blue collar workers of various trades, including carpenters, joiners, builders and masons, gardeners, smiths etc. Among the homeless residents of that estate there was also a white collar office worker, a nursing ward orderly and two musicians. The caretaker also mentioned a couple of unemployed white collar workers who are the least troublesome who are happy to get involved in work for the community etc. The residents generally showed their hostile attitude towards the state authorities and the local government, and they had not taken too kindly to re-emigrants. There was also an antagonism between the unemployed industrial workers and the unemployed farm labourers, as the former considered themselves to be cleverer and generally superior.

In the opinion of the estate caretaker, organising spot jobs by the Labour Fund was justified because it made it possible for the unemployed, at least for the time being, to earn some money apart from what they might be receiving from the social care and charity organisations. Work also helped to develop a sense of duty and maintain a sense of being useful to the society. However, there were also views that the Labour Fund drives down the rates for work (offering an hourly rate of 0.50 zloty), thus damaging the labour market and contributing to growing impoverishment of the labourers.

I believe it is reasonably safe to assume that similar relations prevailed on the remaining estates at the time where the unemployed were tenants. 
Phot. 1. The estate of unemployment and homeless at the former Polish National General Exhibition building. Author: Konrad Hoffman, 1935.

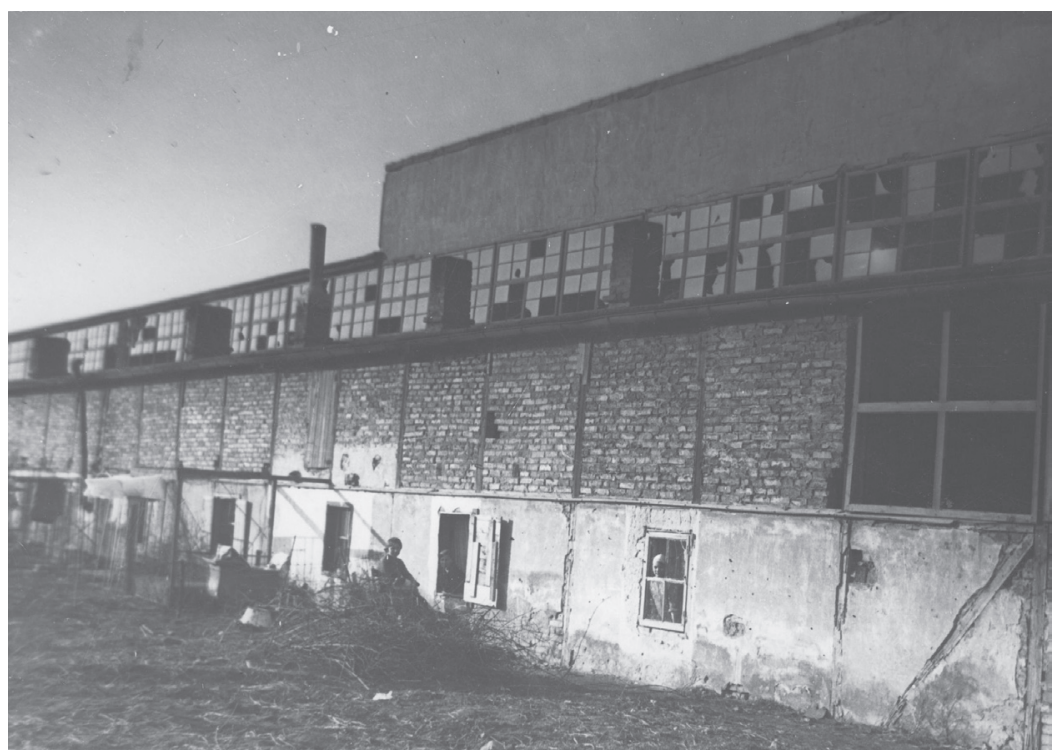

Source: Narodowe Archiwum Cyfrowe, sygn. 1-P-2427-4

Phot. 2. Naramowice. Wooden homes for unemployment and homeless. Author: unknown, c. 1936.

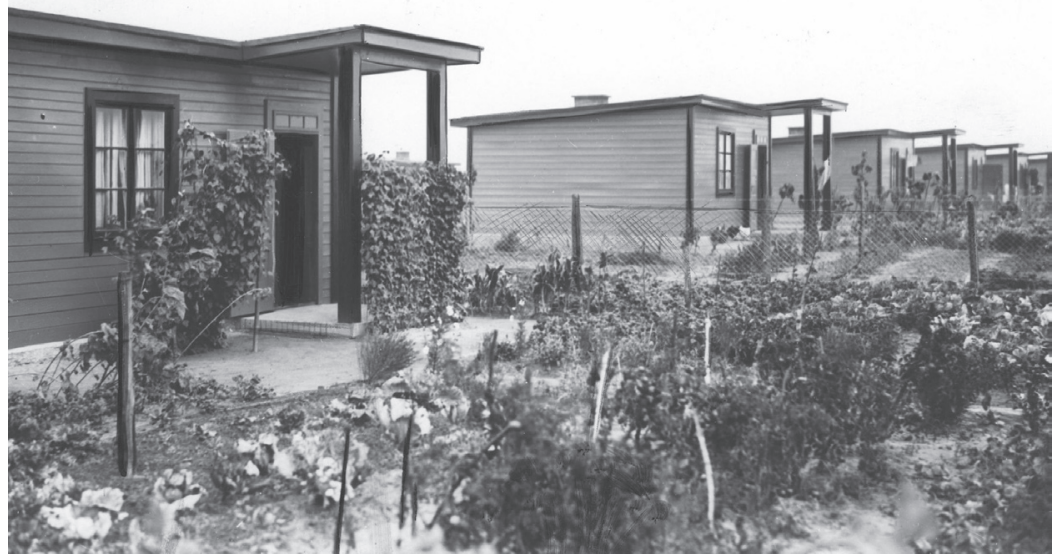

Source: Narodowe Archiwum Cyfrowe, sygn. 1-U-4226. 


\section{CONCLUSIONS}

The PWK Exhibition turned out to be a huge success, the fact which to a certain extent delayed the onset of the economic crisis in Poznan. However, the city was hit by the economic crisis and with no lesser force. The problem of the unemployed and the homeless became so acute that the city authorities started looking at various measures to ease the problem, including some interim solutions. For that reason the decision was made to use the buildings vacated after the closure of the PWK Exhibition, despite the fact that the conditions offered by those buildings failed to meet any standards. Another measure was to establish various types of allotments for the homeless. This initiative helped the unemployed and the homeless to regain a degree of self-dependence and self-sufficiency. The most effective strategy appeared to be the establishing of relative large allotments, around $800 \mathrm{~m}^{2}$, which offered accommodation. The homeless who were transferred to such allotments did gain a genuine opportunity to improve their lot and material standing. Moreover, such a gain did go a long way towards boosting their self-confidence and self-respect. They were no longer homeless because they did own a home and a piece of land. A good illustration of such inspirations and growing self-respect was the case of the residents of the Bałtycka Street Estate who vehemently opposed the use of the popular colloquial name "estate for the homeless" and who went as far as formally applying to the Town Hall to have the name officially changed to "The Rev. Professor Masłowski Estate"79.

We will never know to what extent the existence of special settlements for the unemployed would have impacted the economic situation. The outbreak of the World War II and the subsequent establishing of the Polish People's Republic after the war radically altered the economic reality.

Marcin Graban - PhD, Assistant Professor at Economic History Chair, Adam Mickiewicz University in Poznań. Scientific interests: economic history, industrial relations, labour organizations, trade unions, social inequalities.

79 Towarzystwo Osiedla Hodowli Drobnego Inwentarza im. Ks. Prof. Masłowskiego do zarzadu miejskiego Wydziału Opieki Społecznej z dnia 10.12. 1937 r., dated 10.12.1937, AAP, City of Poznań Records, ref. 4126, p. 11. 